Jurnal Bidan Cerdas
e-ISSN: 2654-9352 dan p-ISSN: 2715-9965
Volume 3 Nomor 3, 2021
DOI: $10.33860 / j b c . v 3 i 3.445$
Website: http://jurnal.poltekkespalu.ac.id/JBC
Penerbit: Poltekk Kemenkes Palu

\title{
Pengaruh Aromaterapi Lemon terhadap Emesis Gravidarum Trimester I
}

\author{
Aida Fitria, Ade Ayu Prawita $₫$, Sari Yana \\ Prodi D4 Kebidanan, Institut Kesehatan Helvetia, Medan \\ $\triangle$ Email Korespondensi: adeamkeb@gmail.com
}

access

\section{ARTICLE INFO \\ Article History:}

Received: 2021-06-21 Accepted: 2021-08-13

Published: 2021-08-31

\section{Kata Kunci:}

Aromaterapi Lemon; Emesis Gravidarum.

\section{Keywords:}

Lemon Aromatherapy; Emesis Gravidarum

\begin{abstract}
ABSTRAK
Pendahuluan: Emesis gravidarum atau mual muntah merupakan hal yang sering terjadi pada kehamilan trimester pertama apabila tidak ditangani akan menimbulkan masalah pada ibu hamil dan janin. Penanganan emesis gravidarum dapat dilakukan dengan pengobatan farmakologis dan non farmakologis seperti aromaterapi lemon. Menurut Riskesdas provinsi Jambi tahun 2018 komplikasi yang dialami ibu hamil sebesar 14,36\% diantaranya mengalami mual muntah. Tujuan: Untuk mengetahui pengaruh aromaterapi lemon terhadap emesis gravidarum pada ibu hamil trimester I di Klinik Bidan Rosita Desa Pasar Senin Provinsi Jambi tahun 2020. Metode: Desain penelitian dalam penelitian ini adalah menggunakan desain pendekatan PreExperimental Design dengan bentuk One Group Pre-test and Post-test. Populasi penelitian sebanyak 20 orang. Teknik pengambilan sampel dalam penelitian ini adalah non probability sampling dengan teknik purposive sampling sebanyak 15 orang, uji statistik yang digunakan adalah uji $t$ dependen. Hasil : Data yang diperoleh yaitu pre-test nilai mean 10,20 dan SD 1,486 sedangkan post-test nilai mean 4,80 dan SD 1,234. Dari hasil uji statisik yaitu dengan uji $\mathrm{t}$ independen dengan tingkat kepercayaan 95\%, diketahui nilai $p=0,000$. Kesimpulan: Ada pengurangan frekuensi emesis gravidarum trimester I dengan pemberian aromaterapi lemon Aromaterapi Lemon
\end{abstract}

\section{ABSTRACT}

Introduction: Emesis gravidarum or nausea, vomiting, which often occurs in the first trimester of pregnancy, if left untreated, will cause problems for pregnant women and the fetus. Handling of emesis gravidarum can be done with pharmacological and non-pharmacological treatments such as lemon aromatherapy. According to Riskesdas Jambi province in 2018, complications experienced by pregnant women amounted to $14.36 \%$ of them experienced nausea and vomiting. Objective: To determine the effect of lemon aromatherapy on emesis gravidarum in pregnant women in the first trimester at the Rosita Village Midwife Clinic, Pasar Monday, Jambi Province in 2020. Method: The research was pre-experimental design approach in the form of one group pre-test and post-test. The study population was 20 people. The sample were taken by using a purposive sampling technique amounted to 15 respondents, the statistical test used was the depnden $t$ test. Result: The data obtained the pre-test mean of 10,20 and SD of 1.486, while the post-test of mean of 4,80 SD of 1.234. From the results of the statistical test, namely the paired t-test with a confidence level of $95 \%$, it is known that the $p$ value $=0.000$. Conclusion: There is frequency reduction in first trimester emesis gravidarum by giving lemon aromatherapy Lemon Aromatherapy in Trimester I Pregnant Women. 


\section{PENDAHULUAN}

Emesis gravidarum merupakan hal yang sering terjadi pada kehamilan trimester pertama dengan prevalensi kejadian di Indonesia sekitar $50-80 \%$ diantaranya pada primigravida $60-80 \%$ dan multigravida $40-60 \%$ (Setyowati ER, 2018). Hal ini disebabkan karena adanya perubahan hormon pada ibu hamil yaitu adanya peningkatan hormon chorionic gonadotropin (HCG) serta hormon progesteron yang menyebabkan pergerakan dari usus kecil, kerongkongan, dan perut yang menyebabkan rasa mual selain itu mual dan muntah juga dapat disebabkan karena kekurangan vitamin B6 (Ini, 2016). Komplikasi dari emesis gravidarum adalah hyperemesis gravidarum yang dapat mengakibatkan tubuh ibu akan melemah, dehidrasi, muka pucat, serta darah akan menjadi kental karena adanya perlambatan peredaran darah sehingga oksigen dan makanan jaringan akan berkurang. Jika oksigen dan makanan untuk jaringan berkurang maka akan membahayakan kondisi ibu dan janin yang ada dalam kandungan (Setyowati ER, 2018). Muntah yang berlebihan dapat menyebabkan pecahnya pembuluh darah kapiler pada lambung dan esofagus sehingga ibu akan muntah bercampur darah (Manuaba, 2008).

Menurut Word Health Organization (WHO) tahun 2015 menunjukkan bahwa terdapat 216 kematian ibu per 100.000 kelahiran hidup akibat komplikasi kehamilan dan persalinan, sedangkan jumlah total kematian ibu diperkirakan mencapai 303.000 kematian di seluruh dunia. WHO tahun 2013 juga mencatat jumlah kejadian emesis gravidarum mencapai $12,5 \%$ dari seluruh jumlah kehamilan di dunia, sedangkan kejadian hiperemesis gravidarum antara 0,3-3,2\% dari seluruh jumlah kehamilan di dunia. Angka kejadian hiperemesis gravidarum di Norwegia 0,5-2,0\%, Turki 1,9-2\%, Pakistan 1,9\%, Jepang 3,6\%, Malaysia 0,3-2\%, Indonesia 1-3\% (Ning Atiqoh, 2020).

Menurut Survei Demografi dan Kesehatan Indonesia (SDKI) tahun 2017, delapan dari sepuluh $(81 \%)$ wanita tidak mengalami komplikasi selama kehamilan. Diantara wanita dengan komplikasi kehamilan, $5 \%$ mengalami pendarahan yang berlebihan, 3\% mengalami muntah terus-menerus dan pembengkakan kaki, tangan dan wajah atau sakit kepala dengan kejang, $2 \%$ mengalami mulas dan ketuban pecah dini 9 bulan yang lalu, dan $8 \%$ wanita mengalami masalah kehamilan lainnya, termasuk demam tinggi, epilepsi dan pingsan, anemia, dan hipertensi (Badan Kependudukan dan Keluarga Berencana Nasional, 2017).

Menurut laporan Nasional Riskesdas Tahun 2018 tentang gangguan/komplikasi yang dialami ibu selama kehamilan diantaranya $20 \%$ ibu yang mengalami muntah/diare terus menerus, 2,4\% demam tinggi, 3,3\% hipertensi, 0,9\% janin kurang bergerak, 2,6\% perdarahan pada jalan lahir, 2,7\% keluar air ketuban dan bengkak kaki disertai kejang, 2,3\% batuk lama, 1,6\% nyeri dada/ jantung berdebar, serta 7,2\% gangguan/komplikasi lainnya (Badan Litbangkes Kementrian RI, 2019). Hasil laporan Provinsi Jambi Riskesdas Tahun 2018 tentang gangguan/ komplikasi yang dialami ibu selama kehamilan diantaranya $14,36 \%$ ibu yang mengalami muntah/diare terus menerus, 2,76\% demam tinggi, 2,24\% hipertensi, 0,46\% janin kurang bergerak, 1,86\% perdarahan pada jalan lahir, 1,46\% keluar air ketuban, 1,20\% bengkak kaki disertai kejang, 1,57\% batuk lama, 0,89\% nyeri dada/ jantung berdebar, serta 3,09\% gangguan/komplikasi lainnya (Badan Litbangkes Kementrian R.I., 2019).

Penanganan emsis gravidarum dapat dilakukan melalui tindakan farmakologi maupun non farmakologi. Tindakan non farmakologi yang biasa disarankan oleh tenaga kesehatan seperti menganjurkan ibu hamil untuk melakukan aromaterapi (Sari Dewi \& Yulia Safitri, 2018). Aromaterapi lemon adalah suatu cara penyembuhan penyakit dengan mengggunakan minyak esensial lemon, dimana 2-3 tetes minyak 
essensial lemon pada kertas tisu atau saputangan yang ditempelkan pada hidung dan dihirup aromanya dapat mengurangi mual dan muntah. Minyak essensial dapat memengaruhi aktivitas otak melalui sistem saraf yang berhubungan dengan indera penciuman. Respon ini akan mampu merangsang produksi penghantar saraf otak (neurotransmiter), yang berkaitan dengan pemulihan kondisi psikologis. Efektivitas zat aktif dapat membantu mengurangi produksi prostaglandin dan berperan penting dalam mengontrol rasa sakit dan keseimbangan hormonal, termasuk mengurangi mual dan muntah (Jaelani, 2017).

Hasil survei awal yang dilakukan peneliti di Klinik Bidan Rosita Desa Pasar Senin Provinsi Jambi peneliti mewawancarai 4 orang ibu hamil trimester I yang mengalami mual-muntah tentang bagaimana cara mereka mengatasi mual-muntah, mereka mengatakan saat mengalami mual-muntah mereka hanya berbaring ditempat tidur untuk mengurangi rasa mual-muntah, mereka sangat jarang mengomsumsi obat anti muntah bahkan minum air putih saja mereka merasa mual, saat saya bertanya apakah mereka pernah mengatasi mual-muntah dengan cara tidak menggunakan obat-obatan (non-farmakologi) seperti teknik akupuntur, akupresur, hipnoterapi, ekstrak jahe, aromaterapi lemon, lalu mereka menjawab tidak pernah melakukan hal tersebut. Penelitian ini bertujuan untuk mengetahui pengaruh aromaterapi lemon terhadap emesis gravidarum pada ibu hamil trimester I di Klinik Bidan Rosita Desa Pasar Senin Provinsi Jambi tahun 2020.

\section{METODE PENELITIAN}

Desain penelitian dalam penelitian ini adalah menggunakan desain pendekatan pre-experimental design dengan bentuk one group pre-test and post-test. Penelitian ini dilakukan di Klinik Bidan Rosita Desa Pasar Senin terletak di Parit 10 Desa Pasar Senin Kecamatan Pengabuan Kabupaten Tanjung Jabung Barat Provinsi Jambi. Penelitian dilakukan pada bulan April - Oktober. Populasi dalam penelitian ini adalah seluruh ibu hamil trimester 1 yang memeriksakan kehamilan di Klinik Bidan Rosita Desa Pasar Senin dengan keluhan emesis gravidarum pada bulan AgustusSeptember 2020. Teknik pengambilan sampel adalah non probability sampling tidak acak (non random) dengan teknik purposive sampling. Sampel dalam penelitian ini sebanyak 15 orang dengan kriteria inklusi adalah lbu hamil yang bersedia menjadi responden, sadar atau kapabel, tidak dengan suatu penyakit dan mengalami mual pada usia kehamilan 0-12 minggu.

Variabel independen penelitian yaitu intervensi essensial oil lemon dalam bentuk aromaterapi namun dalam penelitian ini tidak dikaji untuk essensial oilnya. Intervensi yang diberikan berupa aromaterapi lemon dalam bentuk essensial oil instan setiap pukul 06.00 WIB dengan cara meneteskan 2-3 tetes aromaterapi lemon ke tissu atau handuk kecil lalu dihirup selama 5-10 menit yang dilakukan selama 1 minggu. Sedangkan variabel dependen yaitu emesis gravidarum yang dinilai sebelum dan setelah 1 minggu pemberian intervensi, menggunakan kuesioner yang berisikan pertanyaan tentang frekuensi mual muntah dengan hasil ukur berkurang dan tidak berkurang. Metode pengumpulan data dalam penelitian ini menggunakan metode primer yaitu data diperoleh secara langsung dari hasil kuesioner yang dibagikan kepada responden dan data sekunder yaitu data yang diperoleh dari data kunjungan ibu hamil yang mengalami emesis gravidarum di Klinik Bidan Rosita Desa Pasar Senin Provinsi Jambi Tahun 2020. Analisis penelitian teridiri dari univariat dan bivariat. Hasil uji normalitas didapat data berdistribusi normal sehingga Uji statistik yang digunakan yaitu uji t dependen (paired samples test). 


\section{HASIL PENELITIAN}

berikut:

Berdasarkan hasil penelitian yang telah dilakukan, dapat disusun sebagai

Tabel 1. Distribusi Frekuensi Karakteristik Responden Berdasarkan Umur, Pendidikan, Pekerjaan dan Paritas di Klinik Bidan Rosita Desa Pasar Senin Provinsi Jambi

\begin{tabular}{lrc}
\hline Karakteristik Responden & $\mathbf{n}$ & Persentase (\%) \\
\hline Umur & & \\
$\quad<20$ tahun & 1 & 6,7 \\
$20-35$ tahun & 13 & 86,7 \\
$\quad>35$ tahun & 1 & 6,7 \\
Pendidikan & & \\
$\quad$ SD & 3 & 20,0 \\
SMP & 9 & 60,0 \\
SMA dan Sarjana & 3 & 20,0 \\
Pekerjaan & & \\
$\quad$ IRT & 13 & 86,7 \\
PNS & 2 & 13,3 \\
Paritas & & \\
$\quad$ Nulipara & 7 & 46,7 \\
$\quad$ Primipara & 5 & 33,3 \\
$\quad$ Multipara & 3 & 20,0 \\
\hline
\end{tabular}

Tabel 1, dari hasil dengan 15 orang ibu hamil menunjukkan mayoritas ibu berumur $20-35$ tahun sebanyak 13 orang $(86,7 \%)$, mayoritas berpendidikan SMP yaitu 9 orang $(60,0 \%)$, mayoritas pekerjaan sebagai IRT sebanyak 13 orang $(86,7 \%)$, dan mayoritas paritas nulipara dengan jumlah 7 orang $(46,7 \%)$.

Tabel 2. Distribusi frekuensi Pengaruhuh Aromaterapi Lemon Terhadap Emesis Gravidarum pada Ibu Hamil Trimester I di Klinik Bidan Rosita Desa Pasar Senin Provinsi Jambi

\begin{tabular}{clccccc}
\hline Kelompok & Variabel & $\mathrm{N}$ & Mean & SD & SE & P \\
\hline Ibu Hamil & Pre test & 15 & 10,20 & 1,320 & 0,341 & 0,000 \\
& Post test & 15 & 4,80 & 1,265 & 0,327 & \\
\hline
\end{tabular}

Tabel 2. menunjukkan bahwa hasil pengukuran pengaruh aromaterapi lemon terhadap emesis gravidarum dari 15 orang ibu hamil pada pretest diperoleh nilai ratarata 10,20 (Emesis gravidarum sedang), SD 1,320, SE 0,341 sedangkan post tes nilai rata-rata 4,80 (Emesis gravidarum ringan) SD 1,265, SE 0,0327.

\section{PEMBAHASAN}

Ibu hamil yang mengalami emesis gravidarum tidak sembuh secara keseluruhan saat diberikan aromaterapi lemon dikarenakan aromaterapi adalah jenis pengobatan pencegahan dan manfaaat dari aromaterapi adalah sebagai terapi pendukung (support therapy), walaupun demikian aromaterapi lemon dapat menurunkan tingkat emesis gravidarum sehingga dapat mencegah dampak buruk yang dapat ditimbulkan dari emesis gravidarum seperti hiperemesis gravidarum.

Berdasarkan uji normalitas didapatkan nilai Shapiro Wilk didapat nilai pre test 0,153>0,05 dan post-test 0,230>0,05 artinya data terdistribusi normal. Kemudian dilakukan uji ststistik dengan uji t dengan tingkat kepercayaan $95 \%$ dan nilai $\alpha=0,05$ 
maka dapat diketahui nilai $p=0,000<0,05$ yang artinya ada pengaruh aromaterapi lemon terhadap emesis gravidarum pada ibu hamil trimester I di Klinik Bidan Rosita Desa Pasar Senin Provinsi Jambi tahun 2020 dan dapat dilihat adanya penurunan tingkat emesis gravidarum setelah diberikan aromaterapi lemon dimana dari 15 orang 1 orang mengalami emesis gravidarum ringan dengan skor 6 menjadi 3, 13 responden mengalami emesis gravidarum sedang skor 7-12 menjadi emesis gravidarum ringan skor $\leq 6$ dan 1 mengalami emesis gravidarum sedang tetap menjadi sedang hanya saja skornya bekurang dari 12 menjadi 7 .

Aromaterapi lemon dapat mengurangi mual muntah karena memiliki kandungan limonene. Limonene merupakan komponen utama dalam senyawa kimia aromaterapi lemon yang dapat menghambat kerja prostaglandin sehingga dapat mengurangi rasa nyeri, mengontrol siklooksigenase I dan II, mencegah aktivitas prostaglandin dan mengurangi rasa sakit termasuk mual muntah (Nurulicha, 2020). Berdasarkan hasil penelitian didapatkan hasil sebelum diberiakan aromaterapi lemon dari 15 orang, 14 orang mengalami emesis gravidarum sedang yaitu menjawab pertanyaaan dengan skor 7-12 dan 1 orang mengalami emesis gravidarum ringan dengan skor 6 , setelah dilakukan pemberian aromaterapi lemon selama 4 hari berturut-turut lalu dilakukan pengukuran kembali dimana terjadi penurunan yaitu 14 orang mengalami emesis gravidarum ringan dengan skor $\leq 6$ dan 1 orang mengalami emesis gravidarum sedang dengan skor 7 .

Penelitian ini sejalan dengan yang dilakukan oleh Dainty Maternity dkk menunjukan bahwa hasil uji statistik dengan uji t dependent didapatkan nilai $P$-value $0,000<0,05$ yang artinya ada pengaruh inhalasi aromaterapi lemon terhadap morning sickness pada ibu hamil. Aromaterapi dapat menurunkan skor frekuensi morning sickness selama kehamilan karena aromanya yang segar, membantu meningkatkan atau menjaga kesehatan, merangsang semangat, gairah, menyegarkan dan menenangkan jiwa serta merangsang proses penyembuhan (Maternity et al., 2016).

$\mathrm{Hal}$ yang sama dengan penelitian yang dilakukan oleh Astriana dkk menunjukan bahwa hasil uji statistic dengan uji $t$ dependent didapatkan nilai $p=0,000$, artinya ada pengaruh lemon inhalasi aromatherapy terhadap mual pada kehamilan. Aromaterapi dapat mengurangi frekuensi mual selama kehamilan karena ketika minyak atsiri dihirup, molekul masuk ke rongga hidung dan merangsang sistem limbik di otak. Sistem limbik adalah area yang mempengaruhi mood dan memori, yang berhubungan langsung dengan kelenjar adrenal, kelenjar pituitari, hipotalamus, dan bagian tubuh yang mengatur detak jantung, tekanan darah, stres, memori, keseimbangan hormon, dan pernapasan (Muchtaridi, 2015). Hasil ini juga sejalan dengan penelitian yang dilakukan hasanah, dkk diperoleh terdapat pengurangan emesis gravidarum trimester I dengan pemberian aromaterapi lemon di Kelurahan Binjai Serbangan dengan hasil sebesar 11,20 dan standar deviasi 5,554 (Pratiwi Harahap et al., 2020).

Secara teoritis cara mengatasi mual muntah selama masa kehamilan dapat dilakukan melalui tindakan farmakologi maupun non farmakologi separti pemberian aromaterapi lemon (Sari Dewi \& Yulia Safitri, 2018). Ketika menghirup zat aromatik atau minyak esensial lemon, biomolekul dilepaskan, dan sel reseptor di hidung mengirim impuls langsung ke indera penciuman di otak atau sistem limbik di otak. Sistem limbik berkaitan erat dengan sistem lain yang mengontrol memori, emosi, hormon, seks, dan detak jantung, kemudian segera merangsang impuls untuk melepaskan hormon, hormon dapat menenangkan orang, menghasilkan rasa tenang, dan mempengaruhi fisik dan mental orang. perubahan. Mengurangi mual dan muntah ibu. Trimester pertama kehamilan (Cholifah \& Nuriyanah, 2019). 
Mekanisme aroma lemon adalah proses stimulasi sistem penciuman melalui senyawa aromatik yang diproduksi di sistem limbik otak kecil. Ketika aroma senyawa dihirup, senyawa tersebut dengan cepat berinteraksi dengan sistem saraf pusat dan secara langsung merangsang saraf di sistem penciuman, dan kemudian sistem ini merangsang saraf di otak di bawah keseimbangan korteks serebral. Senyawa aroma yang relatif volatil masuk ke rongga hidung melalui inhalasi, dan molekul aroma yang terhirup diterima oleh sel saraf epitel olfaktorius (ujung sel saraf) dengan 50 sinapsis, kemudian molekul aroma ditransmisikan ke indera penciuman dalam bentuk informasi. Pusatnya terletak di belakang hidung, dan kemudian sel-sel saraf menafsirkan bau dan mengirimkannya ke sistem limbik otak, thalamus (Muchtaridi, 2015).

Menurut Peneliti penggunaan aromaterapi lemon sebagai pengobatan norfamokologi untuk mengatasi mual muntah adalah hal yang baik, karena selama ini pengobatan mual muntah menggunakan pengobatan farmakologi seperti obat obatan. Penanganan mual muntah dengan aromaterapi lemon akan lebih memudahkan dan praktis yaitu dengan meneteskan 2-3 tetes aromaterapi ke tissue kemudian dihirup secara perlahan di waktu yang sama saat ibu belum melakukan aktifitas fisik. Aromaterapi lemon dapat mengurangi tingkat emesis gravidarum karena pada saat dihirup aromaterapi menghambat pengeluaran serotin sehingga serotin dalam darah tidak berkurang, jika serotin dalam darah tidak mengalami penurunan maka mualmuntah tidak akan meningkat.

\section{SIMPULAN DAN SARAN}

Kesimpulan penelitian ini bahwa ada pengurangan frekuensi emesis gravidarum trimester I dengan pemberian aromaterapi Lemon di Klinik Bidan Rosita Desa Pasar Senin Provinsi Jambi tahun 2020. Disarankan agar bagi ibu hamil trimester I biasa menggunakan aromaterapi lemon untuk mengatasi mual-muntah, bagi Klinik Bidan Rosita sebagai masukan bagi bidan juga untuk menambah wawasan bidan dalam memberikan penanganan emesis gravidarum pada ibu hamil trimester I dengan menggunakan cara non farmakologi berupa aromaterapi lemon.

\section{UCAPAN TERIMA KASIH}

Peneliti ucapkan terima kasih kepada ibu Klinik Bidan Rosita Desa Pasar Senin Provinsi Jambi yang telah memberikan ijin penelitian dan pegawai sehingga dapat terlaksananya penelitian ini

\section{DAFTAR PUSTAKA}

Badan Kependudukan dan Keluarga Berencana Nasional. (2017). Survey Demografi dan Kesehatan Indonesia Tahun 2017. https://www.bps.go.id/statictable/2020/10/21/2111/laporan-survei-demografi-dankesehatan-indonesia.html

Badan Litbangkes Kementrian R.I. (2019). Laporan Provinsi Jambi Riskesdas 2018. https://kesmas.kemkes.go.id/assets/upload/dir_519d41d8cd98f00/files/Hasil-riskesdas2018 1274.pdf

Badan Litbangkes Kementrian RI. (2019). Laporan Nasional Riskesdas 2018. Badan Litbangkes Kementrian RI. https://www.litbang.kemkes.go.id/laporan-riset-kesehatandasar-riskesdas/

Cholifah, S., \& Nuriyanah, T. E. (2019). Aromaterapi Lemon Menurunkan Mual Muntah pada Ibu Hamil Trimester I. Jurnal Kebidanan Midwiferia, 4(1), 1-7. http://ojs.umsida.ac.id/index.php/midwiferia/article/view/1844

Ini, M. (2016). Nutrisi Pintar Ibu Hamil \& Menyusui Golongan Darah B (I. Rahmadi (ed.)). Bhuana IImu Populer. https://opac. perpusnas.go.id/DetailOpac.aspx?id=962506 
Jaelani. (2017). Aroma Terapi (3rd ed.). pustaka populer obor. https://books.google.co.id/books/about/Aroma_Terapi.html?id=htvEDQAAQBAJ\&redir_e $\mathrm{SC}=\mathrm{y}$

Manuaba, I. A. C. (2008). Buku Ajar Patologi Obstetri untuk Mahasiswa Kebidanan (M. \& P. E. K. Ester (ed.)). penerbit buku kedokteran ECG. https://onesearch.id/Record/IOS3359.slims-1368/TOC

Maternity, D., Sari, D. Y., \& Marjorang, M. U. (2016). Pengaruh Inhalasi Aromaterapi Lemon Terhadap Morning Sickness Pada lbu Hamil Di Wilayah Kerja Puskesmas Tulang Bawang I Kecamatan Banjar Agung Kabupaten Tulang Bawang Tahun 2016. Jurnal Kebidanan Malahayati, 2(3), 115-120. http://ejurnalmalahayati.ac.id/index.php/kebidanan/article/view/581

Muchtaridi, M. (2015). Aroma terapi: Tinjauan Aspek Kimia Medisinal (1st ed.). Graha IImu. https://opac.perpusnas.go.id/DetailOpac.aspx?id=936006

Ning Atiqoh, R. (2020). Kupas Tuntas Hiperemesis Gravidarum (Mual-Muntah Berlebih dalam Kehamilan).

One

Peach

Media. https://books.google.co.id/books/about/KUPAS_TUNTAS_HIPEREMESIS_GRAVIDAR UM_MUAL.html?id=eczzDwAAQBAJ\&redir_esc $=y$

Nurulicha. (2020). Pengaruh Pemberian Inhalasi Lemon terhadap Pengurangan Mual Muntah pada Ibu Hamil Trimester I di PMB Lestari Cileungsi Kabupaten Bogor Tahun 2019. Jurnal $\begin{array}{llll}\text { Kesehatan Husada, 8(1), 157-165. } & \text { 16ra }\end{array}$ https://ojs.stikesindramayu.ac.id/index.php/JKIH/article/view/215

Pratiwi Harahap, H., Oktafirnanda, Y., \& Manggabarani, S. (2020). Efektivitas Serbuk Jahe, Aromaterapi Lemon, Teh Daun Mint terhadap Emesis Gravidarum Trimester 1. Jurnal Riset Kebidanan Indonesia, 4(2), 84-90. http://www.ejournalaipkema.or.id/aipkema/index.php/jrki/article/view/91

Sari Dewi, W., \& Yulia Safitri, E. (2018). Pengaruh Aromaterapi Lemon terhadap Emesis Gravidarum di Praktik Mandiri Bidan Wanti Mardiwati. Jurnal IImiah Kesehatan, 17(3), 48. https://doi.org/10.33221/jikes.v17i3.173

Setyowati ER, H. (2018). Akupresur untuk Kesehatan Wanita Berbasis Hasil Penelitian. Unimma press. https://unimmapress.ummgl.ac.id/akupresur-untuk-kesehatan-wanitaberbasis-hasil-penelitian/ 